\title{
Mission and Ethics in 1 Corinthians: Reconciliation, corporate solidarity and other-regard as missionary strategy in Paul
}

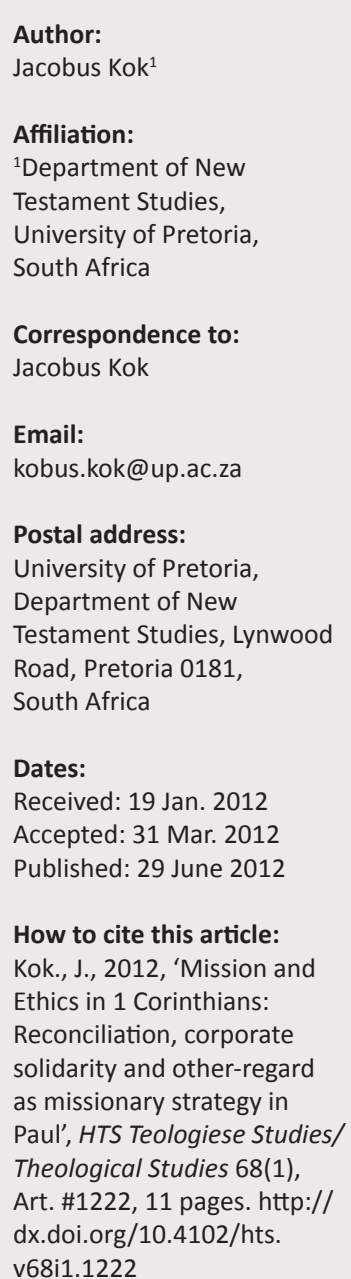

v68i1.1222
In this article the dynamic relationship between mission and ethics in contexts of conflict and change in the Corinthian correspondence was investigated, and the role Paul played as reconciling leader, examined. The early Christian writers like Paul wanted to instruct and shape communities of faith. Paul was especially concerned with the maintenance and growth of his congregations and also with the social and ethical boundaries between the community of faith and the 'world'. In the article it was illustrated that within the Corinthian congregational context there existed several conflict situations, and that much of it was a result of diversity within the congregation. Diversity is a fact of life and reality of the church. In Paul's vision for unity and reconciliation, and in his attempt to address the factionalism in the Corinthian congregation, he would in all cases, ground his practical solution in a theological identity construction. Paul focuses on corporate solidarity and unity and urges the congregation to find their fellow brothers and sisters in times of conflict by means of ethical reciprocity and other-regard, a matter in which he is also an example, typical of other philosophers of his time - but with a significant difference. At the end it becomes clear that Paul's ethical advice has a missional dimension, in the sense that the conflict management should take place in such a way that God is honoured and that both Jews, Greeks and fellow believers will see that the way this community handles conflict, is different to the way the 'world' would do it, and that in the process, even more might be saved.

\section{Conflict over identity and ethos in Corinthians}

Intra-group consensus in the early Christ-movement is nothing less than a myth (contra Munck 1959:135-167). Divisions and conflict existed as natural group dynamic phenomena

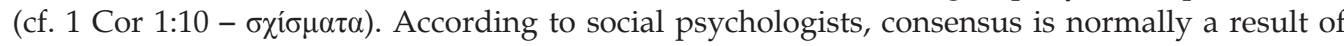
argument, conflict, negotiation and persuasion (Esler 2003:27). From a social scientific point of view group conflict is not always a negative phenomenon. Conflict creates the context in which a group can discern about important identity questions. I agree with Meeks (1993) that:

we cannot begin to understand that process of moral formation until we see that it in inextricable from the process by which distinctive communities were taking shape. Making morals means making community. (p. 5)

Within this context in which distinctive communities took shape, conflict was a natural group dynamic reality.

In 1 Corinthians Paul is addressing not only inter-group relations (1 Cor 12:13) but also intragroup relations $(1$ Cor 8,11$)$. There existed intra-group tensions $(\sigma \chi i \sigma \mu \alpha \tau \alpha)$ and strife about the ethos of everyday life (1 Cor 5-10) and extra-everyday life (1 Cor 11-14) which Paul addresses in his letter after receiving a report from Cloe's people (1 Cor 1:11) in which they asked Paul for some advice on sensitive intra-group conflict matters (Wolter 2006:202-203). Paul then appealed to the congregation to resolve the conflict and factionalism amongst them directed towards unity (Mitchell 1991:200; Robertson 2001:2; Witherington 1995:94-95). ${ }^{1}$

Closer investigation reveals that it is not true that the early Christians agreed on the boundaries of ethos and its dynamic relationship, with regard to identity in the early stages of the Christmovement. Wolter (2006:203-215) distinguishes between three different contexts in which the conflict and questions regarding the dynamic relationship between identity and ethos occurred, intra-congregational social life, extra-congregational social life and extra-congregational private life:

- Intra-congregational social life (1 Cor 11:2-16 and 1 Cor 11:17-34):

- In the context of the ecclesia (intra-ecclesial) some woman prayed and prophesied, and did that purposefully without the proper customary head coverings (1 Cor 11:2, 5). To

1.See Hansen (2010:107) who argues that Paul traces the baptismal unity formula in his argument in favour of social reconciliation. 
some extent it makes perfect sense to argue that this way of conduct was a natural consequence of the radical Pauline (and Christ-following) message of antihierarchical, principal theological equality between male and female (Gl 3:28) and a typical instance of a situation in which the traditional differentiation and inequality could be transcended by not wearing the head coverings which were seen as the symbol of female subjection.

- The Lord's Supper was not held in the community, since there existed divisions in the church ( $\dot{\varepsilon} v \dot{\varepsilon} \kappa \kappa \lambda \eta \sigma^{\prime} \alpha$ ... $\sigma \chi i \sigma \mu \alpha \tau \alpha-1$ Cor 11:18), and everyone was focussed on him or herself, eating alone not taking others into

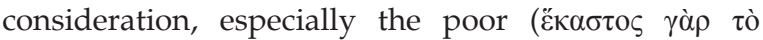

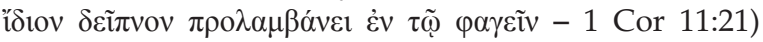
(see Horrell 2005:108-111). ${ }^{2}$ It is clear that the socioeconomic differences between believers, prevalent in the extra-congregational life infiltrated the context of the intra-congregational context.

- Extra-congregational social life (1 Cor 6:1-8; 8:1-13 and 10:23-11:1):

- In 1 Corinthians 6:1-8 the same problem occurs from another angle, namely that some members of the congregation take fellow members to court. The ethos of everyday life spills over in the way the fellow members of the congregation treat each other - that is they solve their problems in the same way that the 'world' does it. The problem is, as Wolter (2006:205) rightly states, that some of the believers were of the opinion that taking fellow Christians to court would not have an impact on their Christian identity since it was something that fell into the category of everyday life. On the other hand, some Corinthian believers seem to have been much more sensitive to the implication of everyday-life identity and ethos on the congregational social life and identity, since some believers asked Paul if a believer should be married to an unbeliever. Obviously they thought that extra-congregational identity influences intra-congregational social life to such an extent that believers had to divorce their unbelieving partners (Wolter 2006:208).

- In 1 Corinthians 8:1-13 and 10:23-11:1 there was disagreement on whether or not meat sacrifices to pagan deities sold on public markets might be eaten by Christ-followers. One group, described as being the 'strong' (those with 'knowledge') said that it was permissible due to the fact that there existed no gods but One God (1 Cor 8:4 - oi̋ $\delta \mu \varepsilon v$ ő $\tau$ ov̉ $\delta \dot{\varepsilon} v$

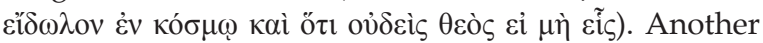
group described as the 'weak' (the superstitious and unlettered - cf. Plutarch, Cam. 6.6; Mor. 119d; Epictet, Diatr. I.8.8) said that it was not permissible for a Christfollower to eat meat that had been sacrificed to a pagan deity. Wolter (2006:205) points to the important fact that it seems that 'both groups were convinced that their Christian identity influences the conduct of everyday life ... but drew completely opposite consequences from this

2.See Horrell (2005:110-113) for a discussion on the relationship between identity and ethos of the Corinthians as a community of $\alpha \delta \varepsilon \lambda \varphi o t$. According to Horrell (2005:113) the kinship language Paul employs creates and evokes the idea of (2005:113) the kinship language Paul employs creates and evokes the idea of
equality where all should uphold the honour and harmony of the family (cf. also Aasgaard 2002:513-530). conviction' (author's own emphasis). At the centre of all these debates lies the question how the identity of the Christ-follower effects everyday ethos.

- Extra-congregational private life (1 Cor 5:1-13; 7:1-40):

- In 1 Corinthians 5:1-13 the same question asked as above is relevant, namely how the identity of the Christfollower effects everyday ethos, and in what way does that stand in continuation or discontinuation to the ethos of everyday life. Where are the boundaries to be drawn and when is Christian identity at stake? In 1 Corinthians 5 the problem revolves around a certain man who lives with his deceased father's wife, most probably an ethos or practice that was typical within the social value system of antiquity, and according to Wolter (2006:206) this cohabitation context might even have existed before the person became a Christian. The natural question is thus to what extent does the fact that the person became a Christ-follower influence or transform his previous ethos. Clearly there existed divisions in the congregation about the matter since it was necessary for Paul to write about it. Some believers might have interpreted the custom as socially acceptable, whilst others felt that it was inappropriate for a Christian to live this way. Paul on the other hand clearly judges it as something that is not even

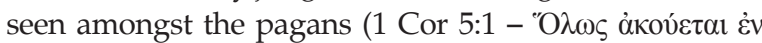

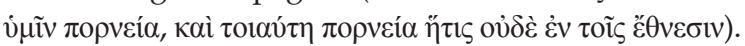

- In another instance (1 Cor 7:1-40) the young believers ask Paul advice on practical matters of sexual ethics, for instance: are Christ-followers allowed to have sexual intercourse (1 Cor 1:1-7); may they divorce and may divorced believers remarry (1 Cor 7:10-11); is it a good thing to get married in the first place (1 Cor 7:25-38)? According to Wolter (2006:207) in 1 Corinthians 7:1 Paul is most probably quoting a thesis from the letter

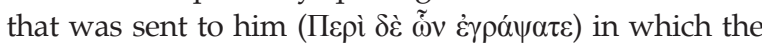
argument goes that: 'it is good for a man not to touch

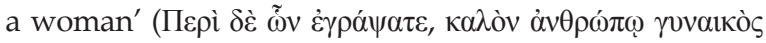

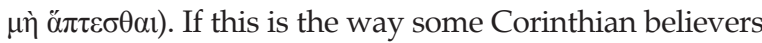
argued, it is in strong contrast to the ethical opinion that others came to, like the person who lived with his deceased father's wife. This brings Wolter (2006) to the very important observation that: 'the spectrum of ethical attitudes concerning the sexual ethos among the Corinthian Christians was rather broad. Moreover, in my view it is remarkable that it took several years from the foundation of the community until these problems had been emerging among its members. In my opinion, this can be further evidence of the thesis that it was the social context of the congregational assembly in which the Christian communities expressed their ethical identity. The quest for the Christian profile of everyday life's ethos emerged only after a considerable delay' (p. 207).

\section{Inter-congregational diversity and conflict}

From the above discussion it becomes clear that everything was not so clear-cut when it came to the dynamic relationship between identity and ethos. Different believers came to different (implicit) ethical conclusions that sometimes 
stood in direct opposition to those of other believers. These differences lead to intra-congregational division and conflict. In the process of the formation of any group natural conflict processes occur, namely forming as a group, storming (conflict), norming (determining roles), performing well as a group and adjourning followed by mourning when the group dissolves or no longer function as a group (Tuckman 1996, [1965] 2001; Smith 2005). The Corinthian congregation formed as a newly created group, a collection of people from different socio-economic, religious and even ethnic contexts which resulted in the storming phase where conflict and schism became a reality that Paul ethically had to address at that stage.

Meeks (1993:5) rightly refers to the fact that all morality is group morality. People reflect ethically in the contexts of a group. In the process of reflection on the dynamic relationship between identity and ethics, some believers came to the conclusion that certain ways of doing things made sense within the framework of their newly found (and forming) Christian identity. The woman who came to the decision that it was better not to wear a head covering in the context of the congregation might have come to such a conclusion based on the transforming message of Paul that there is no difference between man and woman within the community of faith (cf. 1 Cor 12:13; Gl 3:28; Col 3:11). This position could in other words be seen as an example of early Christ-followers 'doing ethics' and coming to a legitimate ethical conclusion that particularised for them not wearing the symbol of status differentiation between men and woman. The same is true for those who regarded meat sacrificed to idols as something that could have no effect on them as a logical consequence of a high Christology (cf. Phlp 2:5-10). For this reason I agree with Wolter (2006:208) that Paul was not the only one 'doing ethics', the believers were also 'fully convinced that their conduct of life was consistent with their Christian identity.'

In this process of ethical reflection, disagreement and conflict, Paul as leader of the community of faith is asked for support after some of Cloe's people told Paul about the conflict that occurred in the faith community (1 Cor 1:11). In the next section the strategy Paul employs to manage the conflict will be investigated.

\section{The conflict management strategy of Paul: Unity, diversity and ethical reciprocity (1 Cor 10:23-24 and 1 Cor 12:13)}

It is well known in current research that ancient Corinth was a highly stratified society in the time of Paul (see Clarke 2006:42; Horrell 1996; Meeks 1983:72-72; Theissen 1982, 2001:27-75) and a 'spearhead for the penetration of Romanitas into the province of Achaea' (Winter 2001:21). Corinth had been refounded as a Roman colony in the year $44 \mathrm{BC}$ by the Roman Emperor Julius Caesar after it had been deserted for almost a century (Clarke 2006:9; Murphy-O'Connor 1983:1-2). Strabo (Geography 8.6.20-23) pointed out that Corinth was mainly occupied and resettled by freedmen, whose move to Corinth entailed an upward social mobility which created an atmosphere characterised by social honour awareness, a focus on wealth and pomp (Clarke 2006:10). It is not possible to say exactly what the ratio between Roman or Greek and Jewish populations were. In 1 Corinthians 1:22-24 Paul refers to the terms 'Iov $\delta \alpha$ ĩo [Jews] and "E $\lambda \lambda \eta v \varepsilon \varsigma$ [Greeks or Pagans], illustrating that in the Corinthian congregation, there possibly were people from both groups, which he would later challenge to express their theological unity in a way that transcends their differences (cf. 1 Cor 12:13). Luke (although not necessarily historical) refers to Aquila and Priscilla who came from Italy, as a result of Claudius' command that all Jews should leave Rome (Ac 18:1-2) (on the Edict, see Seutonius Claudius 25; DioCassius History, 60:6.6; Orosius History, 7:6.15-16). Luke goes on to mention that it were mainly the Jews in Corinth who brought Paul to the tribunal in front of Gallio (Ac 18:12). In Winter's (2001:26) view, it appears that the Corinthians were well aware of Jewish traditions, which gives us the impression that there might have been Jews in that congregation. This is also well described in most commentaries when the use of the Jewish frame of reference in Paul's argument for a particular ethical point of view is discussed, for example in flesh 1 Corinthians 6:16 where Paul quotes Genesis 2:24 as presupposition for his argument (will be discussed below). Numismatic and epigraphical inscriptions give us at least a picture of a new city that drew a diversity of people because of its important strategic position and flourishing economic trading (Clarke 2006:12-13). Plutarch (Moralia 723) draws attention to the fact that the Isthmian games drew a large number of foreign visitors and therefore we get a picture of a diversified city. Archaeological studies (Winter 2001:1-12) and ancient literature (cf. Plutarch Mor 723) illustrate that Corinth in the time of Paul was a city that was particularly characterised by social stratification with many rich people and even more people from the lower margins of society (Theissen 1982:71-73).

The social class difference was one of the reasons for the factionalism in the church that related to the extra-ecclesial status of the believers and the problems it caused within the intra-ecclesial context of the faith community (Clarke 2006:6; Murphy-O'Connor 1983:51-53). Hansen (2010) states the problem well:

What is widely affirmed is that Roman Corinth was a highly stratified and agonistic society and that the pervasive pursuit of status according to a matrix of social valuations was dividing the church. (p. 109)

\section{Exhortation to unity}

Paul's exhortation of social and anthropological unity is done from a theological basis, rooted in God's initiative and missional plan of reconciliation. For Paul, spiritual unity will and should result in outwardly expressed social and anthropological unity in the midst of diversity, without relativising plurality.

In the Christian faith, and especially in Paul, God is the primary subject who reaches out in love to humanity and initiates the process of reconciliation (cf. Breytenbach 2010). The indicative and imperative of the theology of reconciliation is at the heart of the gospel message, but is also a theology that 
seems like foolishness to the wise of this earth, but is wisdom to those who are being saved by the message of the cross (cf. 1 Cor 1:10-4:21). In humbleness, like Christ who gave himself on the cross, unity will be found in the imitatio Christi. Like the popular philosophers of his day, Paul makes use of rhetorical techniques by holding the attention of the reader or hearer by antithesis (1 Cor 1:18), appeal and reference to authority (1 Cor 1:19) and rhetorical questions (1:20) (cf. Keener 2005:27-31). Paul warns that the wisdom of this world blinds the wisdom from God (cf. 1 Cor 1:21; 2:8) and that God's wisdom has the power to transform worldly structures and assumptions. From a worldly perspective of wisdom the death of Christ on a cross is a symbol of brokenness and shame, but for the believer it is God's wisdom at work, and it leads to the expression of God's power and becomes the way in which reconciliation with God is experienced. In Paul's mind, horizontal (people to people) reconciliation is not possible without vertical reconciliation (people with God) in the first instance. God offers his 'power' and his 'wisdom' to believers who are often the 'weak' in this world (cf. 1 Cor 1:28), who implicitly (and sometimes explicitly) challenge the social structures of this world not in a self-boasting way, but in a humble Christ-following way (Keener 2005:28). Christian identity consequently should not have its basis in worldly structures of power, but in Christ. The Corinthians who saw themselves as the wise, the powerful and well-born and who derived their status from that identity, had to go through a status deconstruction and come to a rediscovery of their Christ-following identity, which inevitably would lead to a self-giving life lived in concordance with Christ's selfgiving death on the cross.

In 1 Corinthians 1:10 Paul directly addresses the social discord

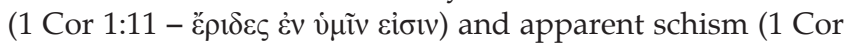

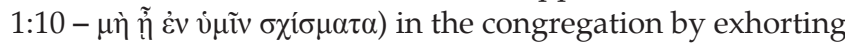
the Christ-followers to be restored in Christ-centred unity:

Now I exhort or beseech you, brothers, in the name of our Lord Jesus Christ, that you all be in agreement and that there be no divisions amongst you, but that you be restored or be perfected or united together in the same mind and in the same judgment. (1 Cor 1:10)

Structurally the passage could be illustrated as follows:

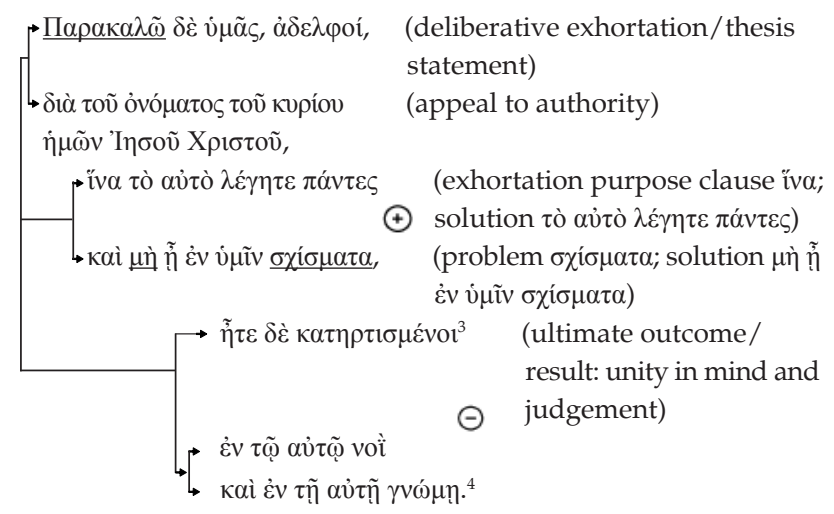

3.The participle here can function in my opinion like an imperative. The passive voice signifies that the subject is being acted upon, and the perfectum wants to communicate not the past action, but the current state of affairs that resulted from the action in question.

4.Translation of 1 Corinthians 1:10 - 'Now I exhort/beseech you, brothers, in the name of our Lord Jesus Christ, that you all speak the same thing and that there be no division in your midst; but that you be restored/be perfected together in the same mind and in the same judgment.'
The theology of reconciliation (and not justification) found here in 1 Corinthians 1:10 and elsewhere (1 Cor 12:13) lies at the heart of Paul's implicit ethical argumentation and the thesis statement for the entire epistle to the Corinthians (Hansen 2010:108). From a rhetorical analytical point of view, Mitchell (1991) came to the same conclusion and a decade before her, also Theissen (1982) and later on Witherington (1995:94) and most recently, Wolter (2006:209) and Hansen (2010:108). Witherington (1995:94) points to the fact that in GrecoRoman rhetoric (cf. P. Oxy. 3057; See Mitchell 1991:64, 200), the proposition in a deliberative discourse (symbouleutikon, cf. Breytenbach 2010:298; Van Unnik 2004) refers to the thesis statement of the entire discourse, that the writer utilises rhetorically to influence and persuade the reader in such a way that he or she should follows a certain (ethical) way of thinking and doing (cf. П $\alpha \rho \kappa \alpha \lambda \tilde{\omega}$ in 1 Cor 1:10 and P. Oxy. 3057). Elsewhere Paul also uses П $\alpha \alpha \kappa \alpha \lambda \tilde{\omega}$ in contexts where he exhorts the believers, for instance in 1 Corinthians 4:16 to imitate him and in 1 Corinthians 16:15 where he urges the believers to accept Stephanas as leader. The latter represents three of the rhetorical strategies Paul utilises in 1 Corinthians to transcend internal divisions:

- Direct exhortation to the parties causing the conflict and division (1 Cor 1:10).

- Exhortation to the believers to follow his example (1 Cor 4:16).

- Exhortation to acceptance of Stephanas as a leader (1 Cor 16:15). (Witherington 1995:95)

Against the background of the status ${ }^{5}$ distinctions between believers referred to above - rich and poor - and the subsequent conflict over identity and ethos that led to factionalism and divisions, Paul exhorts the believers to be one in mind towards the same purpose $(1: 10-\mu \eta ̀ ~ \ldots \sigma \chi i \sigma \mu \alpha \tau \alpha$,

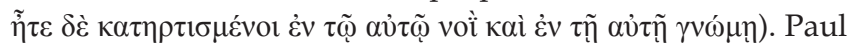
inter alia reminds the readers of their shared alternative identity as children of the same family (1 Cor 1:10 - $\alpha \delta \varepsilon \lambda$ poí), with the implication that their conduct should be aligned in such a way that it brings honour to the head of the household

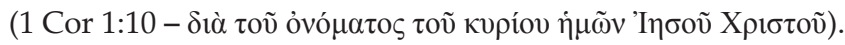
In the first century world 'good' children obeyed their parents and aligned their behaviour in such a way that it reflected the values and ethos of the group to which they belonged (Kok \& Van Eck 2011). Here Paul reminds his readers of their unique ethos as Christ-followers, a family in which unity, concord and other-regard played a significant role for a group that imitated the remembered ethos of its

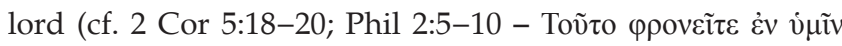

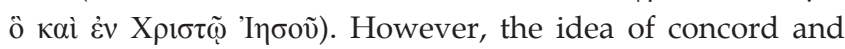
harmony was nothing new in the world of Paul's day, in fact it was not only a slogan in the Greek polis used by political leaders and philosophers alike in contexts of conflict ( $\sigma \tau \alpha \dot{\sigma} 1 \varsigma$ - see Dio Chrysostom, Or. 38.38), ${ }^{6}$ to refer to cosmic, civic and household concord, but also worshiped as the goddess 5.See Theissen (1982).

6.See Van Unnik (2004) and his references to the role concord and peace played in Plutarch, Lucian, Dio Cassius, Epictetus, Dio Chrysostom, Aelius Aristides, et cetera cf. especially Aelius Aristides and Dio Chrysostom (Or. 386-7, 11), Chrysippus in $\pi \varepsilon \rho i$ of. especially Aelius Aristides and Dio Chrysostom (Or. 386-7, 11), Chrysippus in $\pi \varepsilon \rho$. 302, n. 32). For discussions on civic concord in contexts of conflict and change, see Plutarch An. Corp. 4 (501e-502a). 
Concordia in the Roman period (cf. Breytenbach 7 2010:297311). Philosophers like Dio Chrysostom, in line with Stoic tradition, argues in the same way as Paul, that concord has its origin in the divine creator (Or. 38.11 and $48.14 \tau \grave{\alpha} \mu \varepsilon \dot{\gamma} 1 \sigma \tau \alpha$ $\tau \tilde{\omega} v \theta \varepsilon i \omega v \pi \rho \alpha \gamma \mu \alpha \dot{\tau} \omega v)$ and argues in favour of the relationship

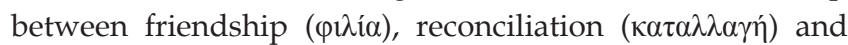

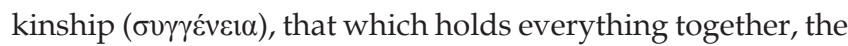
opposite of that being seen as the cause of all destruction ( $\kappa \alpha i$

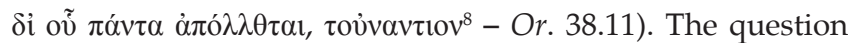
could subsequently be asked, 'So what is new? In what way does Paul differ from the way the philosophers and political leaders spoke about concord in the household and city state?' The answer is simple. Paul might use the same concepts but the ethical basis from which he argues is a world removed from the rhetoric of those in his Umwelt, the household context Paul has in mind is the ecclesia of the Christ-followers. The unity that Paul has in mind does not have its origin in the cosmic order as the philosophers argued, but in Christ. This unity in Christ is nothing less than 'predominant over every social, cultural and ethnic distinction' (Wolter 2006:209). The unity Paul has in mind not only has its origin in Christ, but originally in God's missional plan. In 2 Corinthians 5:18-20 Paul expresses it very clearly when he argues:

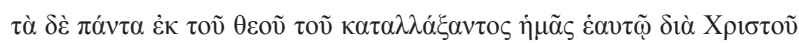

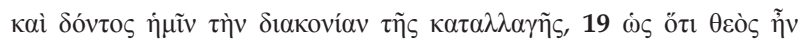

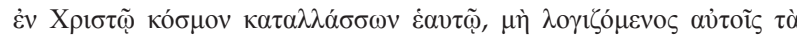

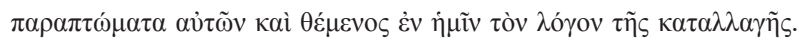

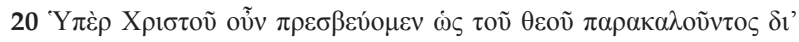

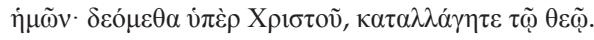

[But] All things are from God, He who reconciled us to himself through Christ, and gave us the ministry of reconciliation; ${ }^{19}$ [against the background of the fact], that God was in Christ reconciling the world unto himself, not reckoning unto them their trespasses, and having entrusted to us the word or message of reconciliation. ${ }^{20}$ Therefore, we are ambassadors on behalf of Christ, as though God were urging by us: we beg you on behalf of Christ, be reconciled to God. (2 Corinthians 5:18-20)

Here it is clear that when it comes to the theme of reconciliation, Paul makes it clear that God is the primary subject of the verb initiating the vision of reconciliation, that Christ is his agent and that believers are to become like ambassadors with a mission for reconciliation. In 1 Corinthians, in the context of conflict and division, Paul employs several metaphors to argue for the sake of reconciliation like the metaphor of a family and household (1 Cor 1:1, 10, 26; 2:1; 3:1; 4:6; 5:11; 6:5; $10: 1 ; 11: 33 ; 12: 1 ; 14: 6,26,39 ; 15: 1,6,50,58 ; 16: 11,15-20$; etc.); a body (1 Cor 6; 10:16-17; 12:27-28; 15:35-46); a building (cf. 1 Cor $3: 9-14 ; 8: 1,10 ; 10: 23 ; 14: 3-5,12,17,26)$, et cetera.

All these metaphors establish the concepts of unity and concord that have as their origin the missional plan of God

\footnotetext{
7.See Breytenbach (2010:297-311) for a discussion of cosmic concord in Hellenistic thought where he discusses Pseudo-Ocellus in De universi natura and also cosmic concord in the civic rhetoric in the Roman Empire, a time in which the use of the ónóvola [concord] terminology increased. In most cases the term is used to civic or household concord.

8.Translation: 'that through which all is destroyed is the opposite [of concord]' (my translation). Cf. originally in Breytenbach (2010:303).
}

who reconciled the world to himself through Christ, who

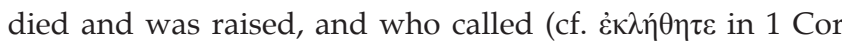
1:10) and empowered believers to continue the reconciling mission of God. In 1 Corinthians 1:10 Paul relates the concept of calling to fellowship with God, his son and their family, calling them 'into common participation in Jesus Christ as well as into common identity with their fellow saints' (Hansen 2010:112). Being called into this family is a call to become

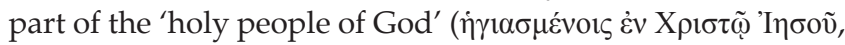

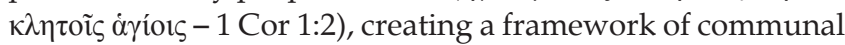
'ethnic' identity in Christ as Hansen (2010:112) convincingly argues:

- God, their father has called them into communal participation with his son, Jesus Christ (1 Cor 1:10). Here Paul employs ethnic identity construction language like genealogy, family, common ancestors (cf. God as father 1 Cor $1: 3 ; 8: 6 ; 15: 24)$.

- Believers are called into becoming a new family in every possible place (1 Cor 1:2) and become brothers and sisters of one another (å $\delta \varepsilon \lambda$ poí occur 41 times, cf. 1 Cor 1:1, 10, 26; $2: 1 ; 3: 1 ; 4: 6 ; 5: 11 ; 6: 5,8 ; 7: 12,14,24,29 ; 8: 11 ; 9: 5 ; 10: 1 ; 11: 33$; $12: 1 ; 14: 6,26,39 ; 15: 1,6,50,58 ; 16: 11,15,20)$, forming a trans-local, fictive kinship group (1 Cor 1:1, 10).

- Paul is like their spiritual father, establishing kinship bonds and a certain way of conduct that should be in line with the ethos he holds forth (1 Cor 4:14-17). (p. 112)

Hansen (2010:112-113) and Meeks (1993:12-13, 37-51) are correct when they observe that in 1 Corinthians and in Paul's other writings, believers constitute a fictive kinship group and that Paul navigates the identity and the ethos of the group in a way that is very typical of ancient kinship norms, like obedience to the paterfamilias, in-group reciprocity, concern for the group's honour and shame and the needs of the group that were seen as more important than that of the individual (cf. Sandnes 1994:103-111).

The opening words of the letter however (1 Cor 1:2) reflect the subtle tension that was a part of the newly formed kinship family in Corinth. They were at the same time the

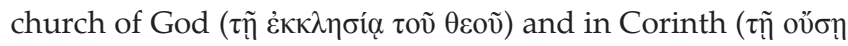
$\dot{\varepsilon} v$ Kopív $\theta \omega)$. Within the language of ethnic theory this poses the problem of maintaining and negotiating boundaries between the intra-congregational and extra-congregational life, between insiders and outsiders (see Hansen 2010:129; Furnish 1999:49). As seen above, the problems in 1 Corinthians concerned intra-congregational conflict and opposing conclusions reached with regard to the particularisation of a believers' ethos when it came to everyday issues of sexuality, marriage and legal proceedings and the Christian ethos within the congregational context like the nature of conduct within worship services, the role of gender, the boundaries between the social group and outsiders, et cetera.

How does Paul steer through these situations of conflict, factualism and discord? Let us first discuss 1 Corinthians 5-7 where sexuality (1 Cor 5:1-13; 6:9-12), lawsuits (1 Cor 6:9-12) and marriage (1 Cor 7$)$ are in focus. 


\section{The boundaries of sexuality and unity in 1 Corinthians 5:1-13}

In 1 Corinthians 1:10, as argued above, we find the thesis statement of the letter in which Paul rhetorically exhorts the believers to restore the unity in their midst and not to tolerate divisions but rather focus on other-regard and corporate identity (cf. 1 Cor 10:23-24). For Paul, unity is a Leitmotif in his theology. All previous ethnic particularities that separated people from one another are transcended in the context of the newly created family God. Therefore, Paul would urge unity in the midst of diversity, making room for cultural differences. He argues that non-Jews should not become Jews, and Jews should not expect nonJews to conform to their cultural ethos and vice versa (cf. 1 Cor 12:13; G13:28). For the sake of unity, diversity should be encouraged and respected as a natural, unavoidable, given reality of life. Elsewhere Kok ${ }^{9}$ (2012) postulated that Paul's theology is one characterised by: 'Prinsipiële ekklesiologiese eenheid, deelname, etiese resiprositeit, diversiteit, vryheid, konsiderasie en sensitiwiteit vir ander, selfopofferende respek' (principal ecclesiological unity, participation, ethical reciprocity, diversity, freedom, consideration and otherregard, self-sacrificial respect) (cf. also Wolter 2006:209).

\section{Wolter (2006) goes so far as to state that:}

Ethical plurality belongs to the essence of Christian communities. However, ... it is the handling of this ethical plurality by which the Christian community has to manifest that the communality of its identity prevails over divergent ethical convictions of its members. (p. 216)

In my opinion Wolter is correct, but I also want to stress that for Paul the norm of unity has its boundaries and within his implicit ethical argumentation, unity and concord is not more important than being called to holiness. Paul makes room for ethnic and cultural plurality, but Paul has clear boundaries when it comes to ethical plurality. These two should not be mistaken or seen as being the same thing. In the implicit structure of his ethical discourse, there is a clear hierarchy of values (see Zimmermann 2013) ${ }^{10}$. In the case where someone in the in-group violates the core value of holiness, such a person will be marginalised for the sake of the protection of the identity and unity of the group (cf.

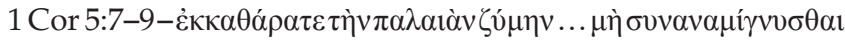

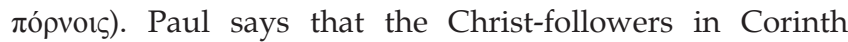
should not even have social contact with such a person

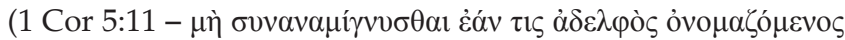
ทิ่ $\pi$ ó $\rho v$ os), for instance not to eat together with them (cf. 1 Cor

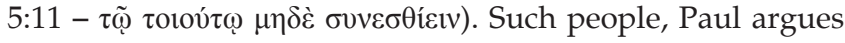
in his concluding sentence, should simply be removed from

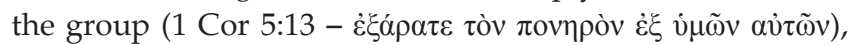

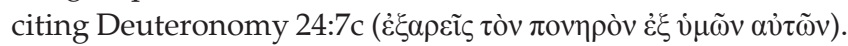

9.http://www.bybelkennis.co.za/Search/newest-first.html?searchphrase=any\&searc hword=kobus+kok\&view=search

10.Zimmermann (2013) makes a convincing case that although Paul was not writing a systematised ethics in the Aristotelian sense of the word, it is possible to explore the implicit ethical argumentation and Begründungszusammenhang between certain values. Zimmermann introduced a methodological process to discover the implicit ethics and one of the steps includes the process to investigate the the implicit ethics and one of the steps includes
'hierarchy of values' in an argument or discourse.
In that sense it is not true to Paul's theology to argue that his vision of communality made room for all kinds of divergent

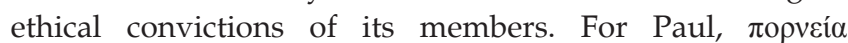
(1 Cor 5:1) is a particularly serious boundary marker not seen as part of the Christian ethos. Some Christians in the Corinthian congregation regarded the conduct of their fellow brother, who lived with his diseased father's wife, as a culturally accepted ethos within the system of social values in Corinth (Wolter 2006:206). For Paul, this is totally unacceptable, since he judges it as being $\pi$ opveía, something

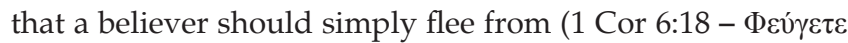
$\tau \eta े v ~ \pi o \rho v \varepsilon i ́ \alpha v)$. Some years earlier, Paul made the same point when he wrote to the Christ-followers in Thessalonica, where we clearly see that Paul viewed sexual relations as a distinctive ethos of Christ-followers, unlike $\pi$ opveí $\alpha$ and $\pi \alpha \dot{\alpha} \theta \varepsilon$ $\dot{\varepsilon} \pi \imath v \mu$ ías which naturally occurred with the pagans who did

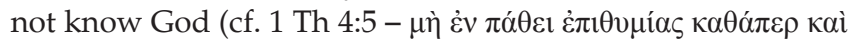

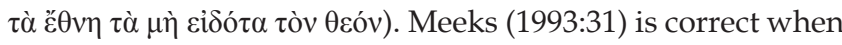
he states that 'Paul explicitly draws the line between insiders and outsiders in moral terms ${ }^{\prime} .{ }^{11}$ Hansen (2010) is thus correct when he argues that the issue of sexual ethics is:

a boundary for this fictive kinship group. Driving him out would be a violation of ethnic solidarity but for the fact that his behaviour has disqualified him from being considered a brother. His concern here is to reinforce the boundaries so as to maintain the group's integrity. (p. 131)

Now, the question is why sexual is ethics such an important matter to Paul? Some argue that Paul's definition of $\pi$ opveía is clearly Jewish, since he quotes Leviticus 18:8 in his argument against it, but then again he departed from other exclusive Jewish ethos like circumcision and food laws (cf. Horrell 2005:134; Wolter 2006:210). Others like Meeks (1993:32) point out that Paul's negative view of sex is not only an exclusive Jewish ethos, but is found in every second pagan moralist, who also boldly spoke against the 'passion of lust' which was seen as the root of all vice. Malherbe (1987, 1989:ad loc 704-705) agrees: 'Paul's advice on sex and greed might not have sounded so strange to someone who heard the teaching of a philosopher like his contemporary Musonius Rufus' (cf. Musonios Rufus, Fragment 12; Epictetus, Dissertation II, 8, 13). However, there is a very important difference between Paul and the popular philosophers when the motivational basis of his ethical point of view is investigated. For Paul, unlike the philosophers, sanctification, holiness and the fact that Christfollowers have fellowship with Christ (participatio Christi) is the reason why they cannot take part in $\pi$ opveí (cf. also 1 Th $4: 3,7,8)$. Malherbe (1987:ad loc 718) argues that the Jews and the Christians both differed with the pagan moralists when it came to the motivation for ethics in the sense that the former always began with God and the latter with reason or nature. Both (Jewish-Christian and Pagan moralists) however agree that this world is known for its passions and lusts that pollute and lead astray (Epictetus, Dissertation II, 8, 13). Both Jews (cf.

11.See Hirsch (2006) who from a modern missionary-ecclesiological point of view is of the opinion that the inclusion of outsiders into the modern church should be made easier, but that we should raise the bar when it comes to making disciples. He says that the church today does it the other way around. Here Hirsch is correct, He says that the church today does it the other way around. Here Hirsch is correct,
especially when one takes this particular Pauline passage into consideration. Although Hirsch is correct, he fails to illustrate his point by using the text of the New Testament. This is often the problem in Missional books, namely that they do new Testament. This is often the problem in Missional books, namely that they do make their points. 
Philo, Virt, 102-103; 181-182) ${ }^{12}$ and Christians (cf. 1 Cor 1:1-2

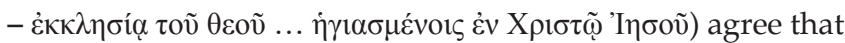

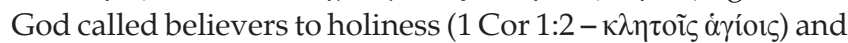
that it inter alia becomes particularised in the form of sexual holiness and the control of sexual lust. Horrell (2005:134) also refers to the adjective $\dot{\alpha} \gamma 10 v$ that places the focus on the fact that God's people are set apart, and that $\alpha \gamma 1 \alpha \sigma \mu$ ó (1 Th 4:3, 4, 7) in 1 Thessalonians for instance, is put in sharp contrast to the sexual immorality of those who are not part of the in-group, in other words those who do not know God (1 Th 4:5). Those who were called to holiness are those who

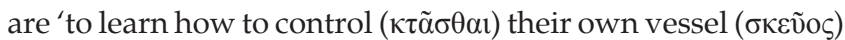
in holiness and honour' (1 Th 4:4). ${ }^{13}$ From the beginning it seems that this was something characteristic of Christian ethics, creating a boundary between the faith community and the outside world. This is also clearly seen in the Epistle of Aristides (Aristides Apology 15.3-7):

[The Christians] are the ones, beyond all the [other] nations of the earth, who have found the truth. For they know the God who is creator and maker of everything, and they worship no other God than him ... They do not commit adultery, they do not engage in illicit sex, they do not give false testimony, they do not covet other people's goods, they honor father and mother and love their neighbours, they give just decisions ...

Their woman are chaste and are virgins and do not engage in prostitution. Their men abstain from all unlawful intercourse and impurity, and all the more the woman likewise abstain, for they look forward to a great hope that is to come (translation by Meeks 1993:8-9).

In my opinion it is clear that both Jews and Christians as well as pagan moralist philosophers (cf. sexual ethics of Stoicism in Hauck \& Schultz 1995:579-595) ${ }^{14}$ see the control over sexual lusts as an important matter since the sexual lust is universal to being human on the one hand (natural like eating and drinking), but those who show control over their sexuality (1 Th 4:4), will also be more likely to show control over other moral aspects of their lives. Sexual control becomes the 'practice ground' of those who lead moral lives. Those who have control over their sexual lusts have illustrated their loyalty to God - they are those who are willing to give up their own needs to a greater purpose. Sexual control is thus put within the framework of showing loyalty and commitment to the group and its symbolic universe. Meeks (1993:30) observes that in the early Christian communities conversion was described as the transformation not only of a way of thinking and of a particular form of life, but also as a transformation of allegiance - from false gods to the only

12.See Meeks (1993:29)

13. Here the control of the vessel is a disputed matter. It can refer to the male sexual organ (cf. 4 Q416) or to the wife. For a discussion on this see Malherbe (2000:224229) who chooses the latter option. For those who favour the male organ, see Elgvin (1997). Since the emphasis here is on self-control, I choose the option of the male sexual organ (cf. also Horrell 2005:134). If it referred only to the wife, then unmarried men would have a problem (cf. 1 Cor 7:36-38). If it referred to the male sexual organ, it would also apply to unmarried men who do not have wife. In 1 Corinthians 7:27 it is clear that Paul is not urging believers to withdraw sexually from their marriat partners, since those who are married should stay so and those who are not married should stay unmarried, since the end is near. so, and those who are not married should stay unmarried, since the end is near. 2005:147).

14. Hauck and Schultz (1995:579) remark: 'Seeking liberation from passion, Stoicism condemns and resists extramarital intercourse, even with female slaves. By condemns and resists extramarital intercourse, even with female slaves. By
unclean acts a person defiles the deity within. Chastity is extolled and adultery unclean acts a person defiles the deity
regarded as unlawful and infamous.' one true God. This implied a radical re-socialisation and a fundamental reformation of morals. ${ }^{15}$ From a social-identity theoretical perspective, this is a good example of how the early Christians used the language of distinction in clear boundary-drawing language between those on the inside and those on the outside (Horrell 2005:138-139). This brings a very interesting tension forward in the way Christ-followers had to draw boundaries between themselves and the world, which directly implicates the missional incarnational dimension of the gospel message, and the way Christians had to live in the world. On the one hand they had to love the world, and on the other they had to hate the world and its impurity (Meeks 1993:52-65).

\section{Corinthians 11:2-16: Paul on boundaries and Christian gender ethos}

Above we referred to the problem of some woman who deliberately prayed without the customary head coverings, and we mentioned that it could have been the (faithful) logical implication of Paul's message of equality amongst believers (1 Cor 12:13; Gl 3:28). The conduct of these particular women caused some problems in the community of faith since some people thought it was inappropriate. In the first century cultural context, 'you were what you wore' in the sense that class differences were very clearly seen in the clothes a person wore (Winter 2003:4-5). Paul as spiritual leader consequently had to address this problem that was also one of the issues that caused division within the faith community of Corinth.

In his handling of the situation Paul argues that the man was not created 'out of' the woman, but the woman 'out of

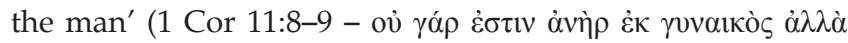

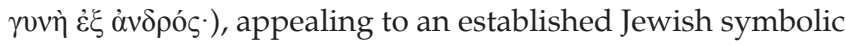
universal frame of reference. In fact, Paul says, women

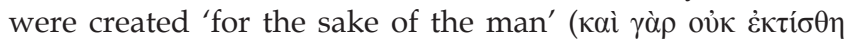

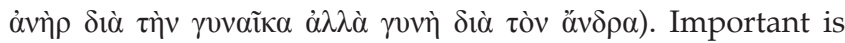
the fact that Paul is not arguing that men are superior to woman. In Christ there is no difference between men and woman since in Christ they share the same status (1 Cor 12:13). Paul does however acknowledge the fact that they do differ on an anthropological level. Said in another way, on a theological level man and woman are equal before God, but on a physical or anthropological level they are different, with the implication that in the social and anthropological context of the culture of Paul's day, they were to respect the particular social conventions ${ }^{16}$ (see Wolter 2006:210-211). In

15.The eating of food was a social boundary marker of the Jews. Paul parts with this Jewish way of defining boundaries. The reason is inter alia that the eating of food for Paul is no moral matter (1 Cor 8:8), but sex is (1 Cor 6:13-14; 10:1-5; 21) Furthermore, Paul's presupposition, as a child of his day, is that sexual intercourse leads to two people becoming one flesh (1 Cor 6:16; Gen 2:24) and therefore kotvovi $\alpha$ has a moral consequence. A Christ-follower is part of the body of Christ and for this reason a Christ-follower cannot have an illicit sexual union and kotvovía with an unbeliever since they are called to be holy (Horrell 2005:150-151).

16.Witherington (1995:235-236) does not agree and argues that Paul is not trying to get the community of faith so far as to endorse typical Roman or Greco-Roman customs, but to establish a new ethos in the church that was common there, but uncommon in the culture, and in this way establishing their own sense of a unique identity. I do not agree with Witherington (1995:236) that 'Paul places little stock in social or cultural agree with Witherington (1995:236) that 'Paul places little stock in social or cultural
conventions or social status.' In my opinion this section is a very good example of how conventions or social status.' In my opinion this section is a very good example of how
Paul takes exactly the cultural ethos of his culture serious in the process of shaping Paul takes exactly the cultural ethos of his culture serious in the process of shaping
Christian communities. One example is 1 Corinthians 9:19-23 where Paul says that to Christian communities. One example is 1 Corinthians 9:19-23 where Paul says that to
those under the law he became like someone under the law, and to those not under those under the law he became like someone under the law, and to those not under
the law he became like them, illustrating that he was indeed sensitive to social customs and the fact that it could hinder or promote the spreading of the gospel. 
my opinion this was a wise decision of the Early Church and also related to the missionary message and ethical integrity of Christ-followers. Even in the later Pauline tradition, for example in Colossians 3, it is clear that the radical message of equality between men and woman that Paul preached (Col 3:11), - and in my opinion, was a continuation of the anti-hierarchical and inclusive message of Jesus (cf. Van Aarde 2001:401-417) - did not in all instances realise into a full-blown social expression of that unity (cf. Col 3:18 -

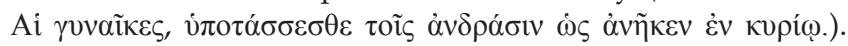
Although the gospel message was a revolutionary one, it seems to me that the primitive and Early Church did not always express the principal theological unity in ways that externally transformed the social systems of the day. This is most clearly seen in the later generation writing of first Peter, where he argues that woman should behave in such a way that within the cultural context of their day, they would be perceived as 'good' wives, and in so doing, their

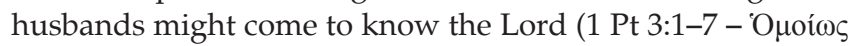

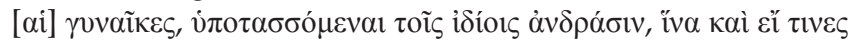

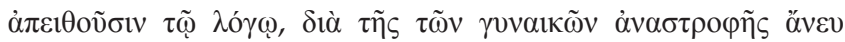

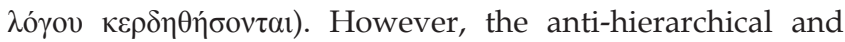
inclusive message of the gospel stayed part of the unique content and motivational basis of the gospel message and did result in forms of reconciliation that interpersonally and internally (over and against external social expression and deconstruction of systems) transformed everyday relations between master and slave, husband and wife and between Jews and gentiles (cf. Eph 2) but not necessarily the outward appearance of the social structure itself. Those who lived within the community of faith and those who lived close to believers would have seen the difference in the motivation and intention of Christian behaviour. Perhaps it is ethnocentric to view Paul and the early Christians as being radically antipatriarchal (in our postmodern sense) and to judge them for not expressing that in more concrete terms. In my opinion, within the early congregations and their theology, this radical message of equality guided social practices and social interaction, but at the same time the early Christians were also sensitive not to give the wrong impression to the outside world. These two should not be seen as being opposed to one another. It rather illustrates sensitivity towards outsiders and has a missional intention (Kok \& Nicklas 2013:iv). Whilst woman were called upon to be subject to their husbands, men were called upon to love and care for their wives, which radicalised the social interaction with the essence of the Christian gospel of love and other-regard. In other words, in outward expression, Paul could urge woman to be subject to their husbands (by wearing head coverings), but this did not deny the basis of their theological unity, which was a revolutionary way of thinking in the first century. In the same way, Paul did not ask the rich to become like the poor, but rather exhorted them to keep the poor in mind when different social groups were together in the congregation. Paul did not urge the abandonment of slavery, but urged the believers to keep their Christ-following identity in mind when interacting with one another, which comes down to Paul's motivation that slaves should be good slaves, and masters should be sensitive to their slaves, not abusing them, but to treat them as brothers in Christ (cf. Phlm) - the point is Paul did not urge for the abandonment of slavery as social institution. This means that Paul did not urge for the destruction of certain social structures, but radicalised social interaction and ethos based on a Christian identity from the inside out, which sprung forth from a different motivational (Christological) basis.

According to Winter (2003:5), in the first century world of Paul's day there were many women who lived like 'the new woman' - a free, independent, emancipated, woman. Augustus (17 BC) made laws that tried to re-establish the traditional 'modest' values against the background of this development of the 'new woman', by promoting and rewarding modest behaviour. Throughout the empire statues were erected that promoted the traditional 'modesty' of matrons. Winter (2003:60-61, 81, 101, 138, 197) also refers to Seneca (Ad Helvian 16.1-4), a contemporary of Paul, who praises his mother who was not like the 'new or modern type of woman', but held to the traditional mores of a modest Roman matron. Against this background it could be postulated that Paul motivated the believers to be sensitive to the social context in which they lived and not to give the wrong impression, and be like these 'emancipated new wives'. Paul reinforced the traditional mores of the time, where women were to be subject to their husbands, and the head covering was a cultural symbol that illustrated that cultural value. This however, does not take away the fact that on a theological level there is no difference between Jew and Greek, free and slave, man or woman (1 Cor 12:13). Paul argues that if women are not sensitive to this cultural aspect, their authority and honour is at stake and therefore Paul's advice here is not meant to degrade the woman to the

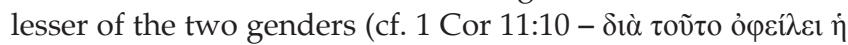

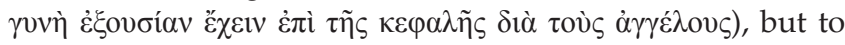
edify (cf. $\dot{\varepsilon} \xi o v \sigma i ́ \alpha v)$ her social position within society or the group. This becomes especially clear in 1 Corinthians 11:12 where Paul says that just as the woman is 'out of' the man, in the same way the man is also 'out of or by' the woman; but even more importantly, and that is his point - all are actually

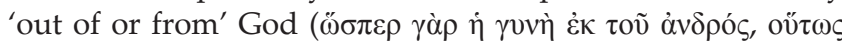

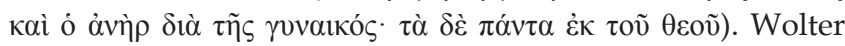
(2006:211) is thus correct when he states that: 'the common

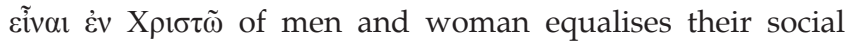
status, but it does not affect their anthropological differences ...' Sexual distinctions between man and woman, according to Paul, are based on the natural order of God's creation and are not obliterated against the background of the believers' redemption and the reality of the new creation in Christ (Witherington 1995:240; Wolter 2006:211). However, Paul makes a strong case for the fact that within their differences, there exists a fundamental unity and equality in Christ (1 Cor 12:13) where status divisions should make way for corporate solidarity and reconciliation. In other words:

corporate solidarity in Christ implies, for Paul, neither the erasure of previous distinctions nor merely their encompassing within a new sphere of belonging, but rather their relativation or revaluation, with real social implications. (Horrell 2005:126)

This message was something fresh in the first-century world. The difference between man and woman is a created given, but the ethical question is how these differences should be managed. In a way this is true for the way other differences 
between people should be handled within the community of faith. As we shall see below, plurality is a given, the challenge is how to manage the plurality in such a way that solidarity becomes apparent in spite of the difference (see Horrell 2005; Wolter 2006:216). As in the other cases where differences occurred, the question is how to make the fundamental unity visible in such a way that 'no one seeks his own, but each

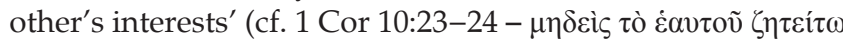

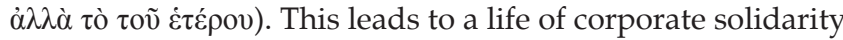
and other-regard, a life of egalitarian ethical reciprocity (Wolter 2006:211), which is an essential Christian ethical value for Paul's strategy for reconciliation. ${ }^{17}$

\section{Corinthians 11:17-34: Intra- congregational status divisions}

The problems with regard to the Lord's Supper, as we have seen above, resulted from the economic status distinctions between the rich and the poor, the haves and the have-nots. The richer Christ-followers were shaming the poorer ones by eating before them, helping themselves to food and drink to the point of satisfaction and even drunkenness, and leaving the poor with the little that was left (Witherington 1996:248). Paul addressed this problem simply by arguing that in the intra-congregational context of the church, the social distinctions should be transcended against the background of their shared unity in Christ. Interestingly enough, Paul does not say that the rich should sell their property and become like the poor (Wolter 2006:211). His ethical advice to the rich is simply that they 'eat at home' and create room so that the poor can have something to eat when the congregation is eating together (Wolter 2006:211; Wolff 1996:262). In 1 Corinthians 11:23-26 Paul grounds his practical solution in a theological identity construction that goes back to the imitatio-Christi narrative that relates to a Jesus-remembered paradigm:

Paulus begründet sein ablehnendes Urteil über die korinthische Mahlpraxis unter Berufung auf die Einsetzung des Herrenmahls durch Jesus. Dort allein - in dem Sterben Jesus 'für euch' (V.24b), das die eschatologische Heilsordnung (V.25b) begründet - sind die Kriterien für ein angemessenes Feiern zu finden. [Paul bases his opinion on the Corinthian meal praxis, citing the establishment of the Lord's Supper by Jesus. There alone - in the death of Jesus 'for you' (v.24b), the eschatological salvation is constituted, and that is where the criteria for a proper celebration of the Lord's Supper is to be found]. (Wolff 1996:263)

By taking part in the Lord's Supper, the believers are remembering Jesus' self-giving life and resurrection and the fact that they are called to concretely live out that particular ethos. A Christian ethos of corporate solidarity and otherregard, a life of egalitarian ethical reciprocity for Paul, should have its clearest expression in the context of the Lord's Supper, the social setting in which the unity of the church could come to its fullest expression, and the absence thereof in this context is nothing less than a 'monstrous violation of Christian unity' (Witherington 1995:247).

17. Wolter $(2006: 209)$ speaks of ethical reciprocity. I expanded the concept and would rather speak of egalitarian ethical reciprocity, due to the fact that the motive of equality in Christ is of such importance to Paul's ethical discourse (cf. GI 3:28; Cor 12:13; Col 3:11).

\section{Corinthians 6:1-8: Extra- congregational conflict between believers}

On the other hand, the nature of Christian ethics is not confined to the social space of the intra-congregational context. It is essentially a way of life that should infiltrate and transform extra-congregational life as well. In 1 Corinthians 6:1-8 Paul addresses the problem of some Christians, probably those with some financial means, who took fellow Christians to court. He reminds them of the fact that they are spiritual brothers (cf. 1 Cor 6:5, 7, 8) and they are part of the same body of Christ, equal in the sight of the Lord and should resolve conflict in a Christ-following way. Instead of getting a 'secular' judge to litigate the case, a fellow in-group member should be the mediating 'facilitator' between the two estranged parties (Wolter 2006:212). The aim is clearly that it should lead to reconciliation - a very important theological and ethical value for Paul (1 Cor 1:10). Paul motivates the believers to manage the conflict in a very particular way, namely that each party should focus not on their own rights and needs, but on those of the other (cf. 1 Cor 10:23-24). In this way the Christian ethos of corporate solidarity and otherregard, a life of egalitarian ethical reciprocity, could transform the 'secular' context of conflict in a 'Christian' way (Wolter 2006:212)

\section{Corinthians 8:1-13: The epitome of other-regard}

Paul's vision of congregational unity and reconciliation finds in my opinion its epitome in Paul's advice regarding the conflict that existed between two Corinthian groups which were labelled the 'weak' and the 'strong'. The conflict existed over the eating of idol meat, as discussed above. In short, some members felt that meat that was offered to an idol could be eaten by Christ-followers since there exists no God but theirs (the so called 'strong'), whilst the other group (the so called 'weak' $)^{18}$ felt that the eating of such 'spiritually contaminated food' could have a negative spiritual effect on them. Paul is comfortable with diversity in this matter as elsewhere, but makes it clear that no grouping's preferences should be imposed on that of another and that other-regard should be central to the handling of conflict that occurs due to diversity and plurality (Hansen 2010:155; Wolter 2006:216). It is very interesting that Paul does not fall into the trap of a lengthy theological discussion on whether it is spiritually beneficial or harmful for a believer to eat idol meat and why that is so. Paul immediately goes on to focus on the issue of conflict management with an eye to facilitate a perspective and code

18.Some scholars are of the opinion that the 'weak' refers to those of lower social standing, who were vulnerable and dependant, socially inhibited and less influential than the 'strong' who were of high social standing and more influentia (cf. Theissen 1982:121-143). Witherington (1995:96) argues rather convincingly that the distinction between the weak and strong could have a sociological basis and refers to the differences between the rich and the poor since it would have and refers to the differences between the rich and the poor since it would have been the rich who would have been invited to participate in temple feasts an those who would have been involved in litigation. On the other hand it could also e interpreted as, that the 'strong' were those who had a firm consciousness of uthority and understood their identity in Christ. I prefer the latter option, but do not exclude the possibility of the former. Both options come down to the point that Paul was sensitive to diverse contexts and different preferences in order to win as many as possible. 
of conduct that would be beneficial for both groups and resolve the crisis situation. What Paul does is to motivate the 'strong' to take the 'weak' into consideration (Witherington 1995:248). Even though he himself (implicitly) agrees with the 'strong' that there could be no negative effect when meat offered to an idol is eaten, Paul nevertheless persuades the 'strong' believers to arrange their conduct in such a way that not their own needs, but the spiritual needs of the 'weaker' believers are taken into consideration when they are confronted with an ethical choice on the matter. By not eating meat offered to idols, the 'strong' would be advancing the spiritual life of the 'weak', whilst the opposite could lead to the 'weak' being led astray (1 Cor 8:9-13) and the unity and health of the church could be jeopardised. Rather than eating meat offered to idols, the 'strong' believers should abstain from eating it, for the sake of the 'weak' believers and their spiritual health (1 Cor 8:13). Here we find the epitome of other-regard and corporate solidarity in action (cf. also Wolter 2006:213). In 1 Corinthians 10:31-32 Paul clearly links this ethical perspective to the missionary dynamics of the Christ-follower movement. He says that all should be done in such a way that it brings God glory, and that it gives no offence to Jews, Greeks or the Church of God. Above all else, the church should be known for the fact that it is different, it handles conflict differently, it holds fast to the love and fellowship of God and the reconciliation of humanity to God and each other - it shows abounding love and other-regard as a fundamental ethos of life, based on a distinct identity -

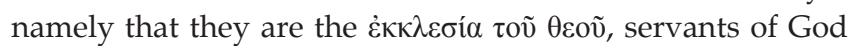
and one another (Wolter 2006:214).

In my opinion the Corinthian congregation was at an early stage of group formation. Typical of the storming and norming phases in-group dynamics and group formation, stereotypical categorisation took place and was related to the experience of social conflict (Smith 2005). Paul resolved the conflict by transcending the stereotypical categorisation. Paul inter alia presented himself as a model of someone who succeeded in not drawing boundaries in such a way that he excluded, but rather missionally included (cf. 1 Cor 9:12; 19-23). ${ }^{19}$ In 1 Corinthians 9:1-23 and the rhetorical climax of the section reached in 1 Corinthians 9:19-23, Paul clearly illustrates that he becomes all things to all men, that he might by all means save some, all for the sake of the gospel

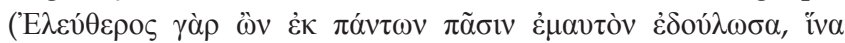

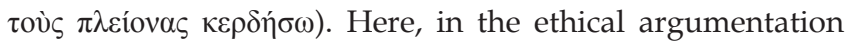
and hierarchy of values 'for the sake of the gospel' and its blessings, serves as the motivational basis of his conduct

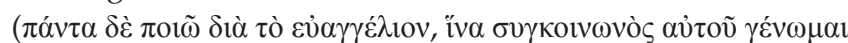
- 1 Cor 9:23). The purpose statement (iv $\alpha \ldots \kappa \varepsilon \rho \delta \eta \tilde{\sigma} \omega^{20}$ ) illustrates that he wishes to 'win some' or save some (ivo

19.Sandness (2011:141) is not completely satisfied that Paul's strategy was successful in fact he thinks it eventually proved impossible to sustain as evident by the fact that seemed that Jewish culture and traditions were more dominant in the context of the development of the mixed churches.

20.Thiselton (2000:701) refers to Daube (1947:109-120) who argues that the term is most probably derived from a commercial background associated with profit and gaining an asset, and probably a technical term in Judaism reflecting the Niphal of the word sakar, namely niskar - which means to gain. Here Paul uses this term that the word sakar, namely niskar-which means to gain. Here Paul uses this term that
might be a technical term associated with winning of gaining a proselyte (cf. Also Mt 18:15 for more on 'winning' disciples).

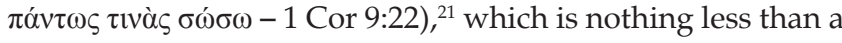
missional ${ }^{22}$ intention. ${ }^{23}$ Furthermore, it becomes clear that in his pastoral leadership strategy (Anpassungstaktik ${ }^{24}$ [Strategy of adaptability]), Paul was sensitive to diversity and adapted himself to the needs of particular groups and in his ethical decisions he guided these groups with that sensitivity in mind (Thiselton 2000:483-484). In my opinion it is clear that when Paul adapted to both the 'weak' and the 'strong', Jews and non-Jews, he illustrated his enculturated sensitivity for other-regard and mutual service as ethical guideline and did not impose a certain lifestyle and cultural way of life in a uniform way, illustrating the importance of enculturating other-regard as missional strategy (cf. also Glad 1995; Thiselton 2000:484; Wolff ${ }^{25}$ 1996:202). The fact that Paul becomes a servant to all, although he is free, is not something that was seen as being 'virtues' in ancient times. Martin (1990:135) (as quoted by Witherington 1995:211) points out that taking a lower station in life was viewed as being slavish or servile behaviour - hardly 'ethically' virtuous. In fact, Paul's metaphor of the leader as slave rejects the status-maintaining leadership framework of the benevolent patriarchy of his day (Martin 1990:135).

In the baptismal unity formula of 1 Corinthians 12:13 (кaì

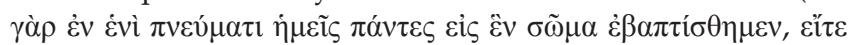

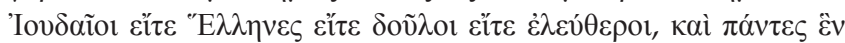

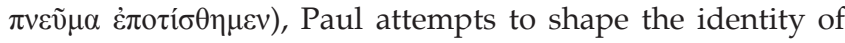
the Christ-followers in Corinth as a reconciling community in contexts of conflict and change (Hansen 2010:155). He does that by reminding them of their corporate identity in Christ that transcends any particular individual identity (cf. Paul's use of $\dot{\alpha} \delta \varepsilon \lambda(\varphi o)$. He appeals rhetorically to them to show self-sacrificial acts of love and other-regard, patterned on Christ's example on the cross (cf. Gl 2:20; 1 Cor 9:19-23; 1 Cor 11:1). In his conflict-management strategy the implicit ethics of reconciliation plays a fundamental important role in Paul's rhetorical argumentation and resolution of the conflict situation. Furthermore, the ethics of reconciliation relates to the narrative of God's reconciling mission (2 Cor

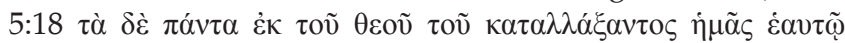

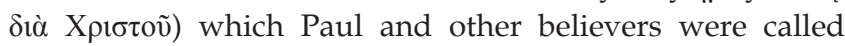

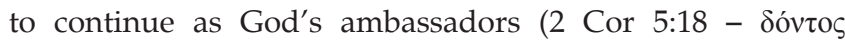

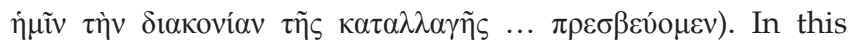

21.It must be made clear that adaptability does not imply that Paul changes the essence of the gospel that he preaches as Wolff (1996:2020) rightly argues: 'Von einer Preisgabe oder auch nur Modifizierung der Grundzüge seiner Botschaft kann jedoch nicht die Rede sein ... dass er ihnen das Evangelium unverkürzt, aber mit einfühlsamen Verhalten so verkündigt, dass sie es in ihrer jeweiligen Situation verstehen und dadurch zum Glauben kommen können.'

22.Wolff (1996:202) also sees Paul's 'Anpassungstaktik' as an 'Ausdruck der Missionssprache': 'Jeder Missionserfolg wird als Gewinn für den Herrn verstanden' and that here we clearly see that 'Paulus konkretisiert seine Missionsmethode.'

23.On Paul's missionary strategy in 1 Corinthians 9:19-23 and the fact that Paul argues in favour of flexibility for the sake of the gospel, see Sandnes (2011:128-141). For a very interesting discussion of the parallels between Paul and Philodemus on the matter of adaptability which was also a strategy that Graeco Roman educators used, in that they also realised the reality of diversity and the need to take different needs into consideration, see Glad (1995).

24.Wolff (1996:202). Witherington (1995:210) agrees and speaks of this section as one in which the modus operandi of Paul is sketched, namely that 'He sees himself as free of obligations from all persons, yet he has made himself a slave to all in order to win over more of them. He accommodates his style of living not his order to win over more of them. He accommodates his style of living, not his food, clothing, and the like.'

25.Wolff (1996:202) also agrees that Paul uses an adaptability strategy: 'Man könnte daraus und auch aus dem folgenden entnehmen, dass der Apostel eine Anpassungstaktik betrieb' [One can see from this and what follows, that the Apostle had an adaptability tactic]. 
way Paul presents the implicit ethics of reconciliation as a universal ethical imperative for the Christ-follower. In the words of Hansen (2010:155), when looking at Paul, 'social solidarity is non-negotiable' in the community of faith - they should be known as being a reconciling people of a reconciling God, both on vertical-theological and horizontal-anthropological levels.

\section{Conclusion}

From the Corinthian congregational context we learned that there existed conflict in the Early Church and that much of it was a result of diversity within the congregation. Diversity is and was a fact of life and reality of the church. In Paul's vision for unity, and in his attempt to address the factionalism in the Corinthian congregation, he does not opt for homogeneity, but accepts diversity as a given. In the midst of conflict he would in all cases ground his practical solution to reconciliation on a common theological identity basis. Paul focuses on corporate solidarity and unity, and urges the congregation to find their fellow brothers and sisters in times of conflict by means of the strategy of corporate solidarity in Christ, ethical reciprocity and other-regard. At the end it becomes clear that Paul's ethical advice also had a missional dimension, in the sense that diversity and conflict management should take place in such a way that God is honoured and that both Jews and Greeks, the weak and the strong, slave and free, as well as fellow believers would see that the way this community handled conflict was different than the world would do it. Christ-followers should be known as a reconciling people, continuing the work of a reconciling God. Perhaps transforming mission could just as well be reconciling mission in contexts of conflict, diversity and change.

\section{Acknowledgements Competing interest}

The author declares that he has no financial or personal relationship(s) which may have inappropriately influenced him in writing this article.

\section{References}

Aasgaard, R., 2002, 'Role Ethics in Paul: The Significance of the Sibling role for Paul's ethical thinking', New Testament Studies 48, 513-530.

Breytenbach, C., 2010, Grace, reconciliation, concord: The death of Christ in GraecoRoman Metaphors, Brill, Leiden.

Clarke, A.D., 2006, Secular and Christian leadership in Corinth: A Socio-historical and exegetical study of 1 Corinthians 1-6, Wipf \& Stock, Eugene, Oregon. (Paternoster Biblical Monographs). http://dx.doi.org/10.1017/S0017816000026316

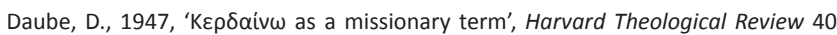
109-120. http://dx.doi.org/10.1017/S0017816000026316

Elgvin, T., 1997, 'To master his own vessel: 1 Thessalonians 4:4 in light of new Qumran evidence', New Testament Studies 43, 604-619. http://dx.doi.org/10.1017/ S0028688500023419

Esler, P., 2003, Conflict and Identity in Romans, Fortress, Minneapolis.

Furnish, V.P., 1999, The theology of the first letter to the Corinthians, New Testament Theology, Cambridge University Press, Cambridge.

Glad, C.E., 1995, Paul and Philodemus:Adaptability in Epicurean and Early Christian Psychagogy, Novum Testamentum Supplementum 81, Brill, Leiden.

Gummere, R.M., [1917] 1953, Seneca: Epistulae Morales I, Harvard University Press, London.

Hansen, B., 2010, All of you are one: The social vision of Gal 3:28, 1 Cor 12:13 and Col 3:11, T\&T Clark, London.
Hauck, F. \& Schultz, S., 1995, 'Porneia', in F.G. Kittel, G. Friedrich \& G.W. Bromiley (eds.), Theological Dictionary of the New Testament, vol. VI, pp. 579-595, Eerdmans, Grand Rapids.

Hirsch, A., 2006, The forgotten ways: Reactivating the missional church, Brazos Press, Grand Rapids

Horrell, D.G., 1996, The social ethos of the Corinthian correspondence: Interests and ideology from 1 Corinthians to 1 Clement, T\&T Clark, Edinburgh.

Horrell, D.G., 2005, Solidarity and difference: A contemporary reading of Paul's ethics, T\&T Clark, New York.

Keener, C.S., 2005, 1-2 Corinthians: New Cambridge Bible Commentary, Cambridge University Press, Cambridge.

Kok, J. \& Van Eck, E. (eds.), 2011, Unlocking the world of Jesus, Biblaridion, Pretoria.

Kok, J., 2012, 'Paulus as kreatiewe ruimteskepper', viewed n.d., from http://www. bybelkennis.co.za/Algemene-Artikels-Bybelse-Temas-en-Sake/Konflikbestuur. $\mathrm{html}$

Kok, J. \& Nicklas, T. (eds.), 2013 [forthcoming], Sensitivity to outsiders: Exploring the dynamic relationship between mission and ethics in the New Testament, Mohr Siebeck, Tübingen. (Wissenschaftliche Untersuchungen zum Neuen Testament II).

Malherbe, A.J., 1987, Paul and the Thessalonians: The philosophic tradition of pastoral care, Fortress, Philadelphia.

Malherbe, A.J., 1989, Paul and the popular philosophers, Fortress, Minneapolis.

Malherbe, A.J., 2000, The letters to the Thessalonians, Doubleday, New York. (AB 32B).

Martin, D.B., 1990, Slavery as salvation: The metaphor of slavery in Pauline Christianity, Yale University Press, New Haven.

Meeks, W., 1983, The first urban Christians: The social world of the apostle Paul, Yale University Press, New Haven.

Meeks, W., 1993, The Origins of Christian Morality, Yale University Press, New Haven. Mitchell, M.M., 1991, Paul and the rhetoric of reconciliation, Mohr Siebeck, Tübingen. Munck, J., 1959, 'The Church without factions: Studies in 1 Corinthians 1-4', in J. Munk (ed.), Paul and the salvation of mankind, pp. 135-167, SCM, London.

Murphy-O'Connor, O.P., 1983, St. Paul's Corinth. Texts and Archaeology, Michael Glazier, Wilmington.

Porter, S.E., 2011, 'Reconciliation as the Heart of Paul's Missionary Theology', in T.J. Burke \& B.S. Rosner (eds.), Paul as Missionary, pp. 169-179, T\&T Clark, London. (Library of New Testament Studies).

Robertson, C.K., 2001, Conflict in Corinth. Redefining the System, Peter Lang, New York. (Studies in Biblical Literature 42).

Sandnes, K.O., 1994, A new family: Conversion and Ecclesiology in the Early Church with cross-cultural comparisons, Peter Lang, Bern. (Studies in the Intercultural history of Christianity 91)

Sandnes, K.O., 2011, 'A Missionary Strategy in 1 Corinthians 9:19-23', in T.J. Burke \& B.S. Rosner (eds.), Paul as Missionary, pp. 128-141, T\&T Clark, London. (Library B.S. Rosner (eds.), Paul as
of Nestament Studies).

Smith, M.K., 2005, 'Bruce W. Tuckman - forming, storming, norming and performing in groups', The encyclopaedia of informal education, viewed 18 January 2012, from http://www.infed.org/thinkers/tuckman.htm

Theissen, G., 1982, The social setting of Pauline Christianity: Essays on Corinth, transl. J.H. Schütz, Fortress, Philadelphia.

Theissen, G., 2001, 'The social structure of Pauline communities: Some critical remarks on J.J. Meggitt, Paul Poverty and Survival', Journal for the Study of the New Testament 24, 72-75.

Thiselton, A.C., 2000, The first letter to the Corinthians, The New International Greek Testament Commentary, Eerdmans, Grand Rapids.

Tuckman, B.W., [1965] 2001, 'Developmental sequence in small groups', Psychological Bulletin 63, 384-399. [Reprinted in Group Facilitation: A Research and Applications Journal (3), Spring 2001], viewed 18 January 2012, from http:// dennislearningcenter.osu.edu/references/GROUP\%20DEV\%20ARTICLE.doc

Tuckman, B.W., 1996, Theories and applications of Educational Psychology, McGraw, New York.

Van Aarde, A.G., 2001, 'Jesus - Kind van God, Vaderloos in Galilea', Verbum et ecclesia 22(2), 401-417.

Van Unnik, W.C., 2004, 'Studies on the so-called First Epistle to Clement: The literary genre', in C. Breytenbach (ed.), Encounters with Hellenism: Studies on the First Letter of Clement, pp. 115-181, Brill, Leiden. (Arbeiten zur Geschichte des antiken Judentums und des Urchristentums 53).

Winter, B.W., 2001, After Paul left Corinth: The influence of secular ethics and social change, Eerdmans, Grand Rapids.

Winter, B.W., 2003, Roman wives, Roman widows: The appearance of New Women and the Pauline communities, Eerdmans, Grand Rapids.

Witherington, B., 1995, Conflict and community in Corinth: A socio-rhetorical commentary on 1 and 2 Corinthians, Eerdmans, Grand Rapids.

Wolff, C., 1996, Der erste Brief des Paulus an die Korinther, Evangelishe Verlagsanhalt Leipzig. (Theologisches Handkommentar zum Neuen Testament).

Wolter, M., 2006, 'Pauline Ethics according to 1 Corinthians', in J.G van der Watt (ed.), Identity Ethics and Ethos in the New Testament, pp. 199-218, Walter De Gruyter, Berlin.

Zimmermann, R., 2013 [forthcoming], 'Implicit Ethics in 1 Corinthians 9', in J. Kok \& T. Nicklas (eds.), Sensitivity to Outsiders, paper presented at the 'Prestige \& T. Nicklas (eds.), Sensitivity to Outsiders, paper presented at the 'Prestige
Conference on Mission and Ethics' at the University of Pretoria, South Africa, 14-16 September 2011, Mohr Siebeck, Tübingen. 